\title{
Tijdelijk werk is eeen crime voor bijstandsgerechtigden
}

D e economie trekt aan en het aantal niet ingevulde vacatures neemt zienderogen toe. Je zou dan ook verwachten dat mensen die afhankelijk zijn van een uitkering vanuit de Participatiewet volop aan de slag kunnen. Zodat ze onder de armoedegrens vandaan omhoog kunnen kruipen naar een menswaardig bestaan, zonder dagelijkse overlevingsstress. Wie wil dit niet? Wie wil niet van het juk van de bijstandsrepressie bevrijd worden?

\section{Pleisterplakkers}

De praktijk en de regelgeving zijn echter veel weerbarstiger. De laaggeschoolden en langdurig werklozen onder ons komen hooguit in aanmerking voor tijdelijke baantjes, als pleisterplakkers op de arbeidsmarkt. Als je een paar maanden boven de bijstandsnorm verdient, dan slaat het systeem op hol en komt de armoedeval om de hoek kijken. Op het doorgeven van veranderingen in je inkomenssituatie is het apparaat niet ingesteld.

Het gevolg is dat je je bijstandsuitkering in ieder geval niet op de reguliere betaaldatum krijgt uitbetaald, als je tijdelijke werk en je maand WW-uitkering er weer op zitten. Of je uitkering wordt eerst geblokkeerd voor nader onderzoek. Of, erger nog: je blijkt ongevraagd uitgeschreven bij de afdeling inkomen van de gemeente.

\section{Kruimels}

Dit gebeurt in de praktijk regelmatig zonder dat de gemeente je hierover (tijdig) informeert. Hierdoor heb je geen gelegenheid gehad om op voorhand te proberen betalingsregelingen te treffen. Met als gevolg een dikke kans op huurachterstand, niet betaalde zorgverzekeringspremie en niet automatisch betaalde energiekosten met de daaraan verbonden en oplopende boetes.

Je bent dan niet alleen de kruimels kwijt die je hebt bijverdient. De weg is door je tijdelijke arbeidsinschakeling geplaveid voor een nieuwe armoedeval. Naast je nieuwe schulden raak je tijdelijk het recht op onder andere de bijzondere bijstand, de eenmalig individuele uitkering en witgoedregeling kwijt. Bij schuldhulpverlening kun je vervolgens veelal niet terecht vanwege een lange wachtlijst en nog niet hoog genoeg opgelopen schuld. En aan het eind van het jaar kan je als klap op de vuurpeil ook nog eens een deel van je zorgtoeslag terugbetalen.

\section{Armoedeschepping}

Deze praktijk van armoedeschepping doordat uitkeringsgerechtigden een tijdelijke arbeidsovereenkomst aangaan, ontbreekt volledig op het netvlies van het ambtelijk en het politieke apparaat met een regulier inkomen.

Hoe lang moeten we nog leven met het mantra dat het je eigen verantwoordelijkheid is als je gevloerd wordt door de verhoudingen op de arbeidsmarkt en door de wet- en regelgeving binnen het sociaal domein?

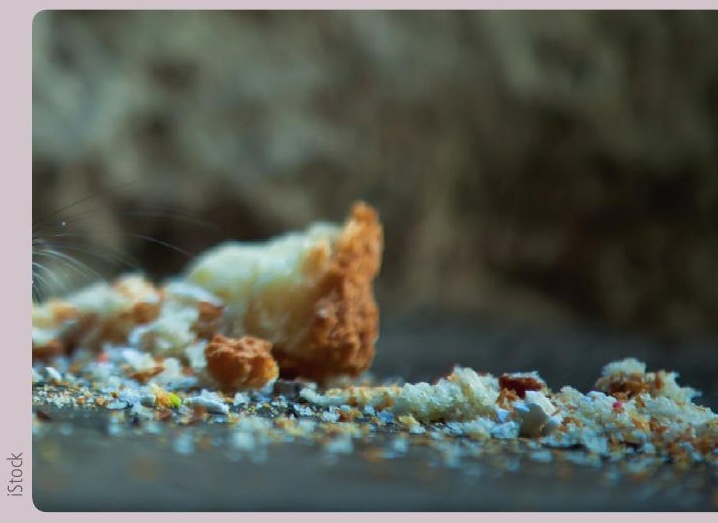

Je bent de kruimels die je hebt bijverdient al snel weer kwijt. inschakeling plaveit

de weg voor een

nieuwe armoedeval

Hans Alderkamp,

lid cliëntenraad Groningen,

op persoonlijke titel 